\title{
Wife's Perception of Contraception Equipment
}

\author{
${ }^{1}$ Dinda Pratiwi, ${ }^{2}$ Muhamad Rizky, ${ }^{3}$ Munaya Fauziah, ${ }^{4}$ Nanda Afina Riyadhu Ilma ${ }^{5}$ Nastiti \\ Dyah Prastiwi \\ Faculty of Public Health, Muhammadiyah University of Jakarta \\ K.H. Ahmad Dahlan St, Cireundeu, Ciputat, South Jakarta, 15419 \\ E-mail: nastitidyah.nd@gmail.com
}

\begin{abstract}
The high birth rate in Indonesia is still a major problem in the population. One of the programs to suppress population growth is through the family planning program. Perceptions of couples of childbearing age regarding family planning have a strong enough influence to determine the use of contraceptives by their wives. This study aims to explore how the wife's perception of contraception. The research method used is qualitative with in-depth interviews. Informants who will conduct indepth interviews are 4 informants who are wives and currently using contraceptives. The results showed that the informants first found out information on the use of contraceptives, namely by health workers. Informants feel that family and self-support affect the use of contraceptives. Informants use contraceptives to control the population, limit birth rates, and regulating birth spacing, informants will feel different discomforts when using contraceptives. informants have the view that Islam does not prohibit the use of contraceptives. Based on this, we can say that the perception of wives in using contraceptives is influenced by several aspects of the information, family support as well as the perception of a wife against contraceptives cheap and tangka it is a benchmark for the wife in the use of contraception other than required by the state. To regulate the distance between pregnancies, the wife also believes in terms of health and religious beliefs that using contraceptives does not violate the norms and beliefs they currently hold.
\end{abstract}

Keywords: Contraceptive Devices, Family Planning, Perception, Religion, Wife. 


\section{INTRODUCTION}

Biological facts attached to women make women have to carry out their life experiences based on their biological functions, such as pregnancy, childbirth, breastfeeding, and also using alcohol to control fertility. The body is the subject that becomes the way humans exist in the world. In addition, the female body is the body of the subject capable of perceiving or interpreting the body. Perception is a process that is preceded by sensing $(1,2)$.

The high birth rate in Indonesia is still a major problem in the population. Since 2004, the family planning program $(\mathrm{KB})$ has been considered to be running slowly, with the birth rate reaching 4.5 million per year, and in 2010 based on the population census it reached 237.6 million people. One of the programs to suppress population growth is through the family planning program. Family planning programs have a role in reducing the risk of maternal death through prevention of pregnancy, delaying gestational age, and spacing pregnancies with the main target being couples of childbearing age (PUS) (3).

Contraceptive family planning is a method recommended by the government to prevent pregnancy. To obtain good results, quality contraception is needed, to improve the reproductive health and sexual health of its users. One of the types of hormonal contraception is the use of contraception. Hormonal family planning is more attractive to EFA because hormonal family planning is proven to be able to prevent pregnancy with a failure rate of $0.25 \%$ and is easy to use (4).

There are three types of hormonal contraceptive methods or short-term methods, namely injections (injections), pills, and implants or implants that are implanted for a certain period. Each method of contraception is very useful to assist families in regulating birth spacing and preventing unwanted pregnancies or limiting the number of children as desired, but on the other hand, every contraceptive method always has side effects that every prospective acceptor must pay attention to. Prospective family planning acceptors need to consult with health workers first, before deciding what type of hormonal family planning method to use. The difference in side effects of each type of contraception causes each married WUS to have different choices for each type of hormonal contraception they want (4).

Perceptions of couples of childbearing age regarding family planning have a strong enough influence to determine the use of contraceptives by their wives.

\section{METHODS}

This study aims to explore how the wife's perception of contraception. This type of research is qualitative using a sample triangulation design approach to determine the wife's perception of contraception. This study was conducted on women who are wives and currently using contraceptives by collecting data through in-depth interviews.

The method used is using qualitative research with in-depth interviews that aim to describe the women's perception of the use of contraceptives were conducted in June 2021. 
The source of information or informants in this study was a wife who used contraception. Sampling was done online via telecommunications to avoid contact during the pandemic. Informants who will conduct in-depth interviews are 4 informants who are wives and currently using contraceptives. Informants were selected based on special characteristics by the research objectives.

Table 1. List of Informant Data

\begin{tabular}{cccc}
\hline Initials Informant & Age & Type Sex & Profession \\
\hline MD & 20 & $\mathrm{P}$ & IRT \\
R & 43 & $\mathrm{P}$ & IRT \\
NA & 40 & $\mathrm{P}$ & IRT \\
ARE & 28 & $\mathrm{P}$ & IRT \\
\hline
\end{tabular}

There are two types of data sources used in this study, namely primary data and secondary data. Primary data were obtained from direct observations in the field with questions that matched the interview guidelines on the use of contraceptives by in-depth interviews, while secondary data were obtained from journals related to this research.

Data validation is done by source triangulation and method triangulation. Source triangulation was carried out using in-depth interviews with predetermined informants using research instruments in the form of interview guidelines. Triangulation methods are being done with in-depth interviews and observation data from the literature. Researchers use this triangulation to ensure the accuracy of the data collected.

This study received permission from a lecturer in the subject of Qualitative Research Methods, Faculty of Public Health, Muhammadiyah University of Jakarta. The interviewer provided information about the study by telephone before conducting the interview, and the informant gave verbal consent before the interview. Interviews were recorded, and informed, sent, and recorded. Interview transcripts are anonymized, as are data analysis and interpretation/ presentations.

The processing and analysis of qualitative data in this study were carried out with the data transcript stage where the data was transferred in the written form completely without changing, adding, or reducing the information contained in the recording. Then a descriptive data analysis was carried out so that conclusions were obtained from the data that had been processed by coding each respondent's answer. The results are illustrated in table 2. 
Table 2 . Interview Data Analysis Results

\begin{tabular}{|c|c|c|c|c|c|c|}
\hline No & Topic & Meaning Unit & Code & Sub Category & Category & Theme \\
\hline \multirow[t]{4}{*}{1.} & \multirow[t]{4}{*}{$\begin{array}{l}\text { When and how } \\
\text { did you first } \\
\text { find out } \\
\text { information } \\
\text { about } \\
\text { contraception? }\end{array}$} & $\begin{array}{l}\text { The first time I found } \\
\text { out about } \\
\text { contraceptives was } \\
\text { after } \\
\text { marriage. Although } \\
\text { previously also knew } \\
\text { a little bit, it's } \\
\text { deeper after marriage }\end{array}$ & $\begin{array}{l}\text { Knowing more } \\
\text { about } \\
\text { contraceptives aft } \\
\text { er marriage }\end{array}$ & After married & \multirow{4}{*}{ Information } & \multirow{4}{*}{ Contraception } \\
\hline & & $\begin{array}{l}\text { After giving birth, } \\
\text { the midwife told }\end{array}$ & $\begin{array}{l}\text { After giving } \\
\text { birth, the } \\
\text { medical team } \\
\text { introduced }\end{array}$ & $\begin{array}{l}\text { postpartum } \\
\text { period }\end{array}$ & & \\
\hline & & $\begin{array}{l}\text { When I was } \\
\text { pregnant, my first } \\
\text { child was notified by } \\
\text { the midwife }\end{array}$ & $\begin{array}{l}\text { When pregnant, } \\
\text { the midwife } \\
\text { informed me. }\end{array}$ & Pregnant & & \\
\hline & & $\begin{array}{l}\text { After the birth, the } \\
\text { midwife notified }\end{array}$ & $\begin{array}{l}\text { After giving birth, } \\
\text { the medical team } \\
\text { introduced }\end{array}$ & $\begin{array}{l}\text { Postpartum } \\
\text { period }\end{array}$ & & \\
\hline
\end{tabular}

\section{RESULTS AND DISCUSSIONS}

Characteristics of Respondents The research was conducted with four wives, aged 2043 years. Contraceptive devices are one of the methods used in the success of family planning programs. The government as the program maker must provide detailed information to the public about the various types and effects and all information related to contraceptives (5).

Based on the results of interviews with informants about how to first find out information about the use of contraceptives, the following are the results of the interviews:

"The first time I found out about contraceptives was after marriage. Even though I already knew a little bit before, but it was more profound after marriage."

"After giving birth, the midwife informed me"

"When I was pregnant with my first child, my midwife told me"

"After the birth, the midwife was notified"

Based on this, it can be said that the informant first found out information on the use of contraceptives, namely by health workers.

The progress of the family planning program cannot be separated from the support from the family because it is closely related to the encouragement or motivation given by the family to PUS for family planning. Family support in the family planning program is a form of family care that contributes significantly to creating quality small families (6).

Based on interviews with informants about whether family members push to put al at the con triceps, following the results of the interview: 
"For the family, there is no one who encourages them to use contraception. In fact, they don't want me to use contraception."."

"No wish alone"

"Aunty"

"Mama"

Based on this, the informants felt that family support had an effect on the use of contraceptives but there were still informants who felt that their desires also affected the use of contraceptives.

The government's policy, for every married WUS using contraception, is intended to provide opportunities for these women to regulate births, foster family resilience, increase the welfare of small, happy, and prosperous families, according to the mandate of Law no. 10 of 1992, concerning population development and the development of prosperous families (4).

Based on the results of interviews with informants about the reasons for using contraceptives, the following are the results of the interviews :

"The reason I use contraception is definitely so that my family is more planned. Because I don't want everything to fall apart. By using contraceptives, we can feel more comfortable planning everything according to what we expect. Everything will be better because it was planned from the start"

"To regulate pregnancy spacing"

"Children are big and old age"

"To delay pregnancy"

This shows that the informants use contraceptives to control the population, limit birth rates, and regulating birth spacing to create a prosperous family.

Several studies have shown that discomfort when using a contraceptive method is one of the reasons a woman leaves her old contraceptive method and switches to a new method (7).

Based on interviews with informants about whether the uncomfortable feeling when using the al at the con triceps, following the results of the interview:

"The discomfort that I feel is that my weight is increasing faster than before, and my period is sometimes less smooth"

"Didn't feel uncomfortable"

"Yes, lower stomach pain"

"Yes, only after injection"

This shows that the informants will feel different discomforts when using contraceptives.

The views of various religions on family planning are that the first is Islam which forbids the types of contraception, vasectomy, and tubectomy because they are permanent, but there is also Islam 
that allows using contraception. Second, the Catholic religion that is allowed is only natural family planning or periodic abstinence, so that other types of contraception are not allowed (8).

Based on interviews with informants about How can religion or belief teach about the course of pregnancy by using contraceptives, the following is the result of the interview:

"In Islam preventing pregnancy is not recommended, but the act is not specifically prohibited. That is, the action may be taken if it is based on the goal of achieving greater benefits. What is forbidden is the use of alcohol to avoid pregnancy out of wedlock."

"There is no prohibition against using contraception"

"The use of contraceptives is permissible in Islam"

"The use of contraceptives is permissible in Islam"

"In Islam, there is no prohibition against using contraceptives"

Based on the results of our research, informants have the view that Islam does not prohibit the use of contraceptives but this is still a difference of opinion for everyone.

\section{CONCLUSIONS AND SUGGESTIONS}

Based on the results and discussion, it can be concluded that the wife's perception of using contraceptives is influenced by several aspects, namely the informant's willingness to use contraceptives due to the information obtained by health workers and the obligation to use contraceptives to regulate pregnancy spacing, support from family and closest relatives as well. This can affect the wife in using contraceptives, besides that, the wife's perception of cheap and affordable contraceptives is a benchmark for wives in using contraceptives. contraception by the wife, in addition to being required by the state in using contraceptives to regulate the distance between pregnancies, the wife also believes in terms of health aspects and aspects of religious belief that using contraceptives does not violate the norms and beliefs they profess at this time.

Therefore, we recommend that husbands continue to support their wives in using contraceptives and if their wives feel uncomfortable using contraceptives that do not suit themselves, it is hoped that they can consult with health workers to find the best solution in using contraceptives and there is a need for discussion and communication as well as an agreement between the wife and husband in using the contraceptives used.

\section{REFERENCES}

1. Hutaminingsih I. Persepsi Perempuan Terhadap Alat Kontrasepsi. 2012;1-22.

2. ASTUTI Y. PERSEPSI ISTRI TERHADAP PENGGUNAAN ALAT KONTRASEPSI IUD DI KABUPATEN KLATEN. \. 2012;32.

3. SITOMPUL HS. PENGARUH PENGETAHUAN, PERSEPSI DAN SIKAP WANITA PASANGAN USIA SUBUR (PUS) TERHADAP PENGGUNAAN METODE KONTRASEPSI 
TUBEKTOMI DI WILAYAH KERJA PUSKESMAS BANDAR KHALIPAH KABUPATEN DELI SERDANG. 2013;

4. Herowati D, Sugiharto M. Hubungan Antara Kemampuan Reproduksi, Kepemilikan Anak, Tempat Tinggal, Pendidikan Dan Status Bekerja Pada Wanita Sudah Menikah Dengan Pemakaian Kontrasepsi Hormonal Di Indonesia Tahun 2017. Bul Penelit Sist Kesehat. 2019;22(2):91-8.

5. Fitriani A. Peran perempuan dalam penggunaan alat kontrasepsi. Masyarakat, Kebud dan Polit. 2016;29(3):121.

6. Puspitasari D, Nurunniyah S. Dukungan Keluarga dalam Keikutsertaan KB pada Pasangan Usia Subur di Desa Argomulyo Sedayu Bantul Yogyakarta. J Ners dan Kebidanan Indones. 2016;2(3):93.

7. Amran Y, Damayanti R. Hubungan Antara Motivasi Keluarga Berencana Dan Persepsi Terhadap Alat Kontrasepsi Dengan Pola Penggantian Metode Kontrasepsi Di Nusa Tenggara Barat. J Kesehat Reproduksi. 2018;9(1):59-67.

8. Dyah Pratiwi E, Sariyati S. Agama dengan Keikutsertaan Keluarga Berencana (KB) dan Pemilihan Jenis Alat Kontrasepsi pada Pasangan Usia Subur (PUS) di Desa Argomulyo Sedayu Bantul Yogyakarta. J Ners dan Kebidanan Indones. 2016;3(1):1. 
Volume I Tahun 2021

November 2021
E-ISSN: 2808-5361

http://e-journal.fkmumj.ac.id/
Proceeding The First Muhammadiyah InternasionalPublic Health and Medicine Conference 